\title{
LEKRA VS MANIKEBU: Perlawanan Majalah Sastra terhadap Politik Kebudayaan Pemerintah Masa Demokrasi Terpimpin (1961-1964)
}

\author{
Oleh: \\ Nurmalia Susanti, Nana Supriatna, Yeni Kurniawati Sumantri ${ }^{1}$
}

\begin{abstract}
This research emerged from the author's interest in cultural magazines' involvement regarding a political situation in Indonesia. The main problem discussed "how was the Sastra magazine's resistance against cultural politics of the Leaded Democracy period in 1961-1964?" The main problem elaborated into four research questions, namely: (1) how was the background of Sastra magazine's publication?; (2) how was the culture concept from Sastra magazine's perspective?; (3) how was the Sastra magazine's efforts to defended its perspective in addressing anti-mainstream cultural concepts?; and (4) how was the impact received by the Sastra magazine due to maintaining the anti-mainstream cultural concept?. The method used in this study is the historical method which is divided into four stages, such as heuristics, criticism, interpretation, and historiography. Based on the study, it can be explained that Sastra published in 1961 was a continuation of Kisah, the publication of this magazine has acted as an effort to provide good reading for the community. In its development, Sastra has its own view of the cultural concept of the Leaded Democracy era, that Indonesian culture is an honest culture that was born from the conscience of the people based on humanity, not based on the slogans of party interests. That was considered not following the spirit of revolution that had not been completed at the time, which led to attacks from various parties, especially from the Lekra. Sastra maintained its stance, one of which was through its involvement in the Manifes Kebudayaan, which was a statement of a group of artists regarding Indonesia's national culture. But not even a year, the Manifes Kebudayaan declared forbidden by President Sukarno because he considered competing with the Indonesian Political Manifesto. The prohibition statement became a trigger for Sastra to disappear from circulation because it was labelled as a tool for the reactionaries.
\end{abstract}

Keywords: Culture and Politics, Leaded Democracy, Sastra Magazine

${ }^{1}$ Nurmalia Susanti adalah mahasiswa Departemen Pendidikan Sejarah FPIPS UPI, Nana Supriatna merupakan Dosen Pembimbing 1 dan Yeni Kurniawati Sumantri merupakan Dosen Pembimbing II. Penulis dapat dihubungi pada email: susantinurmalia2@gmail. com 


\section{PENDAHULUAN}

Suwirta (2008, hlm. 48) menjelaskan bahwa "pers berfungsi untuk memberikan news and views (berita dan opini) kepada masyarakat dan pemerintah." Dengan kata lain pers tidak hanya menyajikan berita saja, namun juga memberikan opini mengenai suatu peristiwa yang sedikit banyaknya dapat memengaruhi pandangan masyarakat. Oleh karena itu pers memiliki peran penting dalam pembentukan opini masyarakat sehingga melalui pers dapat dilihat bagaimana kondisi suatu negara pada suatu zaman.

Pers di Indonesia tidak dapat dipungkiri telah berperan penting dalam sejarah pembentukan negara Indonesia. Mulai dari penyebaran ide nasionalisme yang diawali dari pemikiran para cendekiawan Indonesia yang mulai sadar akan nasib bangsa dan negaranya sendiri, hingga setelah kemerdekaan Indonesia mampu direbut daritangan penjajah pers pun masih berperan dalam kehidupan politik yang tengah berlangsung. Penelitian mengenai pers ini sudah banyak dilakukan, terutama mengenai surat kabar. Namun, masih sedikit kajian pers yang berfokus pada majalah, terutama majalah kebudayaan. Padahal keberadaan majalah kebudayaan di Indonesia juga memiliki bahan-bahan untuk diteliti, misalnya keterlibatan majalah kebudayaan dalam suasana politik yang sedang berlangsung seperti yang akan dibahasa dalam penelitian ini.

Majalah kebudayaan yang akan dikaji adalah Majalah Sastra yang terbit pada tahun 1961 oleh H. B. Jassin. Adapun susunan pengurus majalah ini diantaranya Bambang Munhari sebagai direksi, H. B. Jassin sebagai ketua redaksi, M. Balfas sebagai sekretaris redaksi, D. S. Moeljanto sebagai penyelenggara redaksi, sedangkan untuk bagian ilustrasi memiliki anggota yang cukup banyak yaitu Ekana Siswojo, Toha Mochtar, Tatang M, Zaini, dan A. Wakidjan. Serta bagian tata usaha dipegang oleh Dasimoen. Majalah ini dijual dengan harga eceran Rp. 8,50 untuk daerah Jawa dan Rp. 9 untuk daerah di luar Jawa, sedangkan untuk berlangganan selama 6 bulan dijual dengan harga Rp. 51 untuk daerah Jawa dan Rp. 54 untuk daerah di luar Jawa (Jassin, dkk, 1961a, hlm. 2).

Penelitianinimemfokuskan padakajian mengenai perlawanan majalah Sastra terhadap politik kebudayaan pemerintah tahun 1961-1964. Dengan memfokuskan pada masalah tersebut, penulis ingin menyampaikan bahwa penelitian sejarah tidak hanya bisa dilakukan pada pihakpihak yang berkuasa di satu waktu dan tempat saja, tapi juga bisa dilakukan pada pihak-pihak "kecil". Seperti halnya tokoh "aku, kamu dan dia" dalam buku Prosa dari Praha (Supriatna, 2018) yang menjelaskan mengenai perlawanan para tokoh tersebut sebagai korban dari hegemoni kapitalisme dan konsumerisme. Majalah Sastra juga merupakan media massa yang menjadi korban dari hegemoni pemerintah dalam bidang kebudayaan dan berusaha untuk melakukan perlawanan melalui upayaupayanya dalam mempertahankan pendiriannya terkait kebudayaan nasional Indonesia.

Majalah Sastra tumbuh di tengahtengahkondisipolitikpadamasa Demokrasi Terpimpin. Pada saat itu terdapat sebuah kecenderungan agar setiap seniman harus memiliki pandangan politik dan ikut serta dalam sebuah organisasi politik. Hal tersebut didukung dengan pendirian lembaga kebudayaan dalam tubuh partai- 
partai politik guna menarik massa dan mendukung pandangan politik partainya sehingga partaitersebut memiliki pengaruh besar dalam pemerintahan. Seperti: Lembaga Kebudayaan Nasional (LKN) milik Partai Nasional Indonesia (PNI), Lembaga Seniman Budayawan Muslimin Indonesia (Lesbumi) milik Nahdlatul Ulama, Lembaga Seni Budaya Indonesia (Lesbi) milik Partai Indonesia (Partindo), dan Lembaga Kebudayaan Rakyat (Lekra) milik Partai Komunis Indonesia (PKI) (Moeljanto \& Ismail, 1995, hlm. 9-10).

Tidak seperti seniman pada umumnya, seniman yang terkumpul dalam majalah Sastra adalah seniman yang tidak mau ikut campur dalam urusan politik, seperti yang dijelaskan Mohamad (1993, hlm. 22) bahwa "Para penulis yang mengirimkan karya mereka ke sini umumnya penulis yang tidak - atau belum - tergabung dalam organisasi politik apapun. Bahkan diantara penulis Sastra itu, tampak ada tendensi keengganan memasuki partai yang ada saat itu." Sehingga dalam perjalannya seniman Sastra sering mendapatkan sindiran-sindiran dari seniman yang memiliki pandangan berbeda khususnya dari seniman Lekra seperti julukan "anti Manipol”.

Selain itu, dalam suasana pemerintahan masa Demokrasi Terpimpin yang sedang berfokus dalam upaya mengisi jalannya revolusi yang belum selesai, semua aspek kehidupan dituntut untuk mendukung upaya tersebut, termasuk dalam aspek kebudayaan. Hingga muncullah slogan "Politik sebagai Panglima” yang dipopulerkan oleh Lekra untuk menggaungkan semangat seniman Indonesia agar selalu berupaya mendukung upaya pemerintah. Slogan tersebut dijadikan acuan oleh mayoritas seniman saat itu, terutama yang menyatakan pendirian politiknya dengan memasuki organisasi atau partai politik. Berbeda dengan seniman pada umumnya, seniman Sastra cenderung tidak setuju dengan slogan tersebut karena mengisyaratkan bahwa politik dijadikan apek utama dari segala aspek yang ada di Indonesia.

Adapun mengenai angka tahun yang akan dikaji adalah 1961-1964, peneliti mengambil patokan awal penelitian yaitu pada tahun 1961 karena majalah Sastra memulai penerbitannya pada tahun tersebut tepatnya pada bulan Mei 1961. Sedangkan angka tahun yang djadikan patokan akhir penelitian ini yaitu pada tahun 1964 karena majalah Sastra diberhentikan penerbitannya ketika masa Demokrasi Terpimpin adalah pada tahun tersebut, tepatnya pada penerbitan No. 3 tahun 1964. Meskipun pada tahun 1967 majalah Sastra kembali terbit, namun peneliti tidak mengkaji lebih lanjut karena fokus penelitian yang akan dikaji adalah tentang perlawanan majalah Sastra terhadap politik kebudayaan pemerintah masa Demokrasi Terpimpin.

\section{METODE PENELITIAN}

Metode yang digunakan oleh penulis untuk menjawab permasalahan dalam penelitian ini, adalah metode sejarah dengan menggunakan studi literatur, yang dilakukan dengan membaca dan mengkaji buku-buku, artikel dalam jurnal, surat kabar atau majalah dan dokumen beberapa karya ilmiah lainnya yang menunjang dengan penelitian ini.

Metode sejarah merupakan metode yang sesuai untuk digunakan dalam penelitian ini karena data-data yang 
dibutuhkan menyangkut dengan masa lampau. Seperti yang dijelaskan oleh Ismaun (2005, hlm. 34) bahwa "metode sejarah ialah rekonstruksi imajinatif tentang gambaran masa lampau peristiwaperistiwa sejarah secara kritis dan analitis berdasarkan bukti-bukti dan data peninggalan masa lampau yang disebut sumber sejarah." Selanjutnya menurut Gottschalk (2008, hlm. 39) yang dinamakan "metode sejarah adalah proses menguji dan menganalisis secara kritis rekaman dan peninggalan masa lampau. Rekonstruksi yang imajinatif daripada masa lampau berdasarkan data yang diperoleh dengan menempuh proses itu disebut historiografi atau penulisan sejarah." Dari beberapa definisi di atas dapat disimpulkan bahwa metode sejarah merupakan suatu metode yang digunakan dalam proses penelitian terhadap sumbersumber masa lampau yang dilakukan secara kritis-analitis dan sistematis yang disajikan secara tertulis.

Adapun langkah-langkah yang akan penulis gunakan dalam melakukan penelitian sejarah ini sesuai yang dijelaskan Ismaun (2005, hlm. 48-50) meliputi empat langkah, yaitu:

a. Heuristik, yaitu tahap mengumpulkan sumber sejarah yang relevan dengan topik yang dipilih. Cara yang dilakukan adalah dengan mencari dan mengumpulkan sumber-sumber penelitian berupa artikel dalam jurnal, buku, surat kabar atau majalah, maupun tulisan-tulisan hasil penelitian terdahulu yang berkaitan dengan permasalahan yang dikaji.

b. Kritik, yaitu tahap menyelidiki secara kritis apakah sumber-sumber yang ditemukan relevan dengan permasalahan penelitian baik bentuk maupun isinya. Kritik sumber terbagi menjadi dua yaitu otentisitas atau keaslian sumber (kritik eksternal) dan kredibilitas (kritik internal).

c. Interpretasi, yaitu tahap memberikan penafsiran terhadap fakta-fakta yang diperoleh dengan cara menghubungkan satu sama lainnya.

d. Historiografi, yaitu tahap penyusunan seluruh hasil penelitian dalam suatu penulisan yang utuh dan jelas dengan menggunakan tata bahasa penulisan yang baik dan benar.

\section{HASIL PENELITIAN DAN PEMBAHASAN}

Terbitnya majalah Sastra diawali oleh beberapa peristiwa sebelumnya, seperti polemik tentang krisis sastra Indonesia. Hae (2014, hlm. 2) mengemukakan bahwa "padaawal 1950 mulaimunculkeluhanakan krisis atau kelesuan di dalam kesusastraan Indonesia modern, dan itu berlangsung hingga pertengahan dasawarsa itu". Keadaan tersebut dikatakan polemik, karena ada pendapat yang pro dan kontra mengenai krisis sastra tersebut. Mereka yang berpendirian adanya krisis dalam sastra Indonesia mengatakan bahwa sastra Indonesia pada saat itu sedang dilanda kelesuan, impasse. Antara lain mereka mendasarkan pada tidak adanya dihasilkan roman-roman besar (Eneste, 1987, hlm. 38). Polemik ini semakin memuncak terutama ketika Soedjatmoko (1954) dalam kata pengantarnya untuk majalah Konfrontasi menyatakan bahwa sebetulnya krisis yang terjadi dalam bidang kebudayaan dan kesusastraan merupakan akibat dari adanya krisis kepemimpinan, lebih lanjut dijelaskan bahwa: 
Krisis jang sekarang kita alami, teranglah suatu krisis kepemimpinan. Sebabnja terletak di dalam ketidak mampuan pimpinan nasional untuk menjesuaikan diripada keadaan jang baru, jang kita hadapi sesudah tertjapainja kemerdekaan; pada ketidak mampuannja untuk mengerti bahwa dunia tempat kita telah merebut kedudukan jang lajak, lain sifatnja daripada dunia jang kita lihat dari penglihatan nasionalistis jang terbatas didalam waktu perdjuangan kita terhadap Belanda, dan bahwa dunia itu lain djuga tuntutannja terhadap kita. Maka disinilah letaknja kegagalan para pemimpin kita jang lama, jang telah begitu berdjasa dalam menuntun kita sampai pada pintu gerbang kemerdekaan. Akan tetapi sajang seribu kali sajang, mereka tidak dapat melepaskan diri dari sikap dan alam pikiran jang memang diperlukannja didalam tingkat jang pertama, dan jang telah mendjadi sumber kekuatannja. Padahal keperluan2 untuk tingkat perdjuangan jang kedua berlainan sekali sifatnja. Sifat perdjuangan tingkat pertama ialah politik dalam batas2 jang sempit. Ia ditundjukan terhadap kekuasaan Belanda, makanja sifatnja terutama antitesis. Tuntutan zaman sekarang adalah suatu tuntutan jang memerlukan kekuatan kreatif. (hlm. 9-10).

Soedjatmoko

menitikberatkan pada kelemahan pemimpin Indonesia dalam menjawab tantangan zaman. Menurutnya keadaan sebelum pengakuan kemerdekaan oleh Belanda dan keadaan setelahnya sangatlah berbeda, hal tersebut dikarenakan adanya perbedaan tuntutan. Ketika Belanda masih berdiri di bumi
Indonesia padahal Indonesia sudah memproklamasikan kemerdekaannya, tuntutannya adalah melawan kekuasaan Belanda dan merebut kembali kemerdekaan Indonesia, sedangkan setelah adanya pengakuan kedaulatan Indonesia, tuntutannya menjadi semakin berkembang yaitu bagaimana caranya mengisi kemerdekaan yang sudah direbut dengan susah payah. Untuk menjawab tuntutan tersebut maka dibutuhkanlah kekuatan kreatif, yang mana tidak dikembangkan secara baik oleh para pemimpin Indonesia. Karena pada tahuntahun tersebut pemerintah sedang berfokus pada masalah politik, yang mana Indonesia sedang memberlakukan Demokrasi Liberal dengan sistem pemerintahan parlementer, yang dalam pelaksanaannya justru menimbulkan ketegangan politik karena sering terjadinya pergantian kabinet dan adanya perselisihan antar-partai. Sehingga pada akhirnya menyebabkan krisis di segala bidang terutama dalam bidang kebudayaan dan kesusastraan.

Disamping pendapat di atas, ada juga pendapat sastrawan yang menyatakan bahwa apa yang dikatakan mengenai adanya krisis sastra Indonesia itu tidak benar. Seperti yang disampaikan Jassin dalam ceramahnya pada simposium kedua Fakultas Sastra di Jakarta pada bulan Desember 1954 yang diberi judul "Kesusastraan Indonesia Modern tak ada Krisis”, Jassin (1967a, hlm. 25) menyatakan pendapatnya mengenai krisis sastra adalah sebagai berikut "apa jang dilihat orang sebagai krisis saja kira hanjalah satu pergolakan sewadjarnja dalam satu masjarakat jang sedang mentjari perimbangan-perimbangan baru dan nilainilai baru dalam tjara hidup baru". Dengan kata lain, Jassin menganggap bahwa apa 
yang dipandang orang sebagai krisis sastra sebenarnya itu bukanlah sebuah krisis melainkan sebuah fase yang wajar bagi suatu masyarakat dalam suatu wilayah yang sedang dalam masa peralihan.

Selanjutnya Notosusanto

(1954, Juli) memandang bahwa krisis sastra adalah sebuah mite atau mitos, karena menurutnya pada tahun-tahun tersebut sastra Indonesia masih berkembang dan tidak ada indikasi ke arah kelesuan. Hal tersebut dibuktikannya dengan adanya istilah "sastra majalah". Istilah tersebut timbul karena pada masa itu kehidupan sastra Indonesia lebih banyak tertuang dalam majalah-majalah, yang merupakan akibat dari adanya likuidasi Balai Pustaka, seperti yang dijelaskan Notosusanto (1954, Juli. hlm. 48) bahwa "akan tetapi ada pula kedjadian jang menjedihkan didalam periode ini. Jaitu likwidasi Balai Pustaka! Sehingga sastra Indonesia betul-betul djadi sastra madjalah".

Rosidi (1968) juga menjelaskan terkait kehidupan sastra pada periode itu memang lebih banyak berkecimpung dalam majalah-majalah. Hal tersebut menjadi salah satu sebab mengapa karya sastra yang dihasilkan pada periode tersebut mayoritas hanya berbentuk cerpen, sajaksajak singkat, dan karangan pendek lainnya, lebih lanjut Rosidi menjelaskan sebagai berikut:

... aktivitas sastra terutama hanya dalam majalah-majalah saja... Karena sifat majalah maka karangan-karangan yang mendapat tempat terutama sajak, cerpen, dan karangan-karangan lain yang tidak begitu panjang. Sesuai dengan yang dibutuhkan oleh majalahmajalah, maka tak anehlah kalau para pengarang pun lantas hanya mengarang cerpen, sajak, dan karangan-karangan lain yang pendek-pendek. (hlm. 126).

Salah satu majalah yang berfungsi sebagai wadah sastrawan untuk mempublikasikan karyanya adalah majalah Kisah yang terbit pada tahun 1953, H. B. Jassin juga duduk sebagai tim redaksi di dalamnya. Namun usia majalah Kisah tidak berlangsung lama, kurang lebih hanya empat tahun majalah Kisah akhirnya harus berhenti terbit. Mengenai alasan pemberhentian penerbitan ini Jassin mengungkapkan bahwa majalah Kisah kalah bersaing dengan majalahmajalah hiburan yang pada saat itu sedang ramai. Lebih lanjut Jassin (1967b, hlm. 141) menjelaskan bahwa "Sungguh sajang karena besarnja saingan dari madjalah hiburan dan malah madjalah tjabul jang dibiarkan muntjul dengan suburnja dimasa lalu, sukarlah bagi Kisah untuk bertahan ditindjau dari sudut komersiil."

Kebutuhan akan bacaan yang bermutu bagi masyarakat ternyata masih dirasakan oleh H. B. Jassin, sehingga ia mengusahakan agar Kisah bisa terbit kembali. Akhirnya perjuangan itu membuahkan hasil, hal tersebut terlihat dari surat Jassin kepada Ajip Rosidi tertanggal 14 Februari 1961 (dalam Jassin, 1984, hlm. 208-209) bahwa "Izin terbit Kisah sudah keluar, tapi namanya harus diganti, kami sebut majalah Sastra. Untuk penerbitan pertama direncanakan dicetak 15.00o mulai April depan."

Majalah Sastra terbit untuk nomor pertamanya pada bulan Mei 1961, lebih satu bulan dari perencanaan awal. Dalam perkembangannya, Sastra ternyata memiliki konsep kebudayaan tersendiri dan cenderung tidak mengikuti konsep kebudayaan yang diikuti oleh seniman pada umumnya. Dalam situasi Demokrasi 
Terpimpin yang sedang berupaya mengisi jalannya revolusi yang belum selesai, Sukarno menginginkan agar seniman turut serta dalam upaya tersebut, seperti pernyataan Presiden Sukarno yang dimuat dalam Harian Rakjat berjudul "Bung Karno dan Delegasi Seniman” (1957, 9 Maret) bahwa “... revolusi itu sendiri adalah kebudajaan, sebagaimana halnja djuga politik. Beliau mengharapkan kepada kaum seniman, supaja mentjurahkan dajatciptanja untuk membentuk kepribadian manusia Indonesia.”

Berdasarkan kutipan di atas, dapat diambil simpulan bahwa pemerintahan di bawah Sukarno menginginkan agar para seniman melalui karya-karyanya dapat berpartisipasi dalam jalannya revolusi yang belum selesai ini. Hal tersebut didukung oleh Lekra (Lembaga Kebudayaan Rakyat) dengan semboyannya yaitu "Politik sebagai panglima”. Dengan kata lain, para seniman termasuk sastrawan harus menempatkan politik sebagai acuannya dalam berkarya. Namun, Sastra memiliki pandangan tersendiri, Foulcher (1969) menjelaskan bahwa dalam kata pengantar untuk edisi pertama, Sastra menegaskan bagaimana kedudukannya memandang kebudayaan dalam konstelasi politik yang sedang terjadi saat itu bahwa:

In the preface to the first edition, entitled Kisah Terbit Kembali (Kisah Published Again), Balfas affirmed the determination of the editorial staff to open the magazine's pages to every short story of sufficiently high artistic value. He emphasised their conviction that art was not bound to any one ideology. This was a declaration of continued rejection of political standards in art. (hlm. 435)
Berdasarkan kutipan di atas, dijelaskan bahwa dalam kata pengantar untuk edisi pertama, yang berjudul "Kisah Terbit Kembali”, Balfas menegaskan bahwa staf editorial akan membuka halaman majalah iniuntuksetiap cerita pendekyang memiliki nilai artistik yang cukup tinggi. Dia menekankan keyakinan mereka bahwa seni tidak terikat pada satu ideologi manapun. Ini adalah sebuah pernyataan lanjutan dari standar politik dalam seni. Dengan kata lain, tim redaksi Sastra menyatakan dengan tegas bahwa Sastra tidak terikat dengan aliran politik manapun. Hal tersebut merupakan sebuah keberlanjutan dari apa yang sudah dilakukan dalam Kisah yaitu majalah kebudayaan yang namanya berganti menjadi Sastra. Lebih lanjut tim redaksi menjelaskannya dalam kata pengantar penerbitan Sastra yang berjudul "Kisah Terbit Kembali (sebuah kata pengantar)" (Jassin, dkk, 1961b, hlm. 3) bahwa "Terhadap aliran2 politik dan kejakinan jang saling bertubrukan itu, Kisah menjediakan halamannja bagi setiap tjerita pendek jang baik tanpa melihat pada aliran dan kejakinan. Ukuran satu2nja jang dipakai ialah punja nilai seni atau tidak. Seni bisa hidup pada semua kejakinan.”

Pernyataan sikap Sastra mengenai pendiriannya terhadap situasi politik yang sedang berlangsung juga ditegaskannya dalam kata pengantar penerbitan tahun keduanya yang berjudul "Satu Tahun Sastra Pernjataan Sikap dan Pertanggungandjawab", tim redaksi Sastra (Jassin, dkk, 1962) menjelaskan bahwa:

"Dalam menentukan haluan kami mengambil kebidjaksanaan tidak membontjeng apa jang disebut dalam istilah sehari-hari kiri dan kanan, tapi sesuai dengan tjita-tjita nasional, bertolak dari kepribadian 
sendiri jang bebas memilih dan menentukan untuk pertumbuhan kepribadian diri, berpedoman pada tjita-tjia Pantjasila. Dan kalau kami tidak masuk partai kiri atau kanan, itu bukan berarti bahwa kami tidak punja pendirian, tapi karena baik partai kiri maupun kanan ada kekurangankekurangannja jang harus tetap kami hadapi dengan kritis. Landasan kami adalah perikemanusiaan, kemudi kami akalbudi. (hlm. 3)

Berdasarkan kutipan di atas, terlihat bahwa majalah Sastra tidak berpihak pada kekuatan politik manapun, karena pada dasarnya setiap kekuatan politik memiliki kelemahannya sendiri, dan sikap itupun yang dipegang oleh sastrawan yang aktif di dalamnya. Dalam suasana Demokrasi Terpimpin yang sudah dijelaskan di atas, muncul sebuah trend di lingkungan seniman Indonesia, yaitu untuk mendukung jalannya revolusi yang belum selesai itu maka seniman Indonesia harus menyatakan dirinya masuk ke dalam organisasi sebagai pendirian politiknya. Hal tersebut juga dianjurkan oleh Pramoedya Ananta Toer (dalam Moeljanto \& Ismail, 1995, hlm. 120) bahwa "organisasi adalah penting untuk pendekatan pada objektivitas. Sastrawan membaja diri dalam gerakan masa". Namun, tidak seperti seniman pada umumnya, seniman yang terkumpul dalam majalah Sastra justru memiliki pandangan yang berbeda. Mereka berpendapat bahwa seniman tidak harus masuk ke dalam organisasi atau partai politik untuk mendukung usaha pemerintah. Hal tersebut juga dijelaskan tim redaksi (Jassin, dkk, 1964) dalam kata pengantar penerbitan tahun keempat yang berjudul "Memasuki Tahun Keempat (tahun konfrontasi)" bahwa:

"Mengenai hubungan seniman dan kepartaian kami berpendapat, bahwa seniman tidak wadjib untuk sesuatu partai. Ini bukan berarti, bahwa seniman tidak boleh masuk sesuatu partai jang dijakininja ideologinja. Tentu sadja boleh. Seniman sebagai inti budi nurani masjarakat, lebih merasakan permasalahanpermasalahan pada diri dan djiwanja dan kalau dia seorang jang djudjur, dia akan mengemukakan dalam karja-karjanja apa jang mendjadi impian, harapan, keinginan, tjita-tjita masjarakat dan bangsanja, tapi djuga keketjewaan dan kesedihan, dalam mengalami kegagalan dan kesukaran jang dihadapi dalam pergulatan membangun suatu masjarakat jang adil, makmur dan bahagia”. (hlm. 5)

Berdasarkan kutipan di atas, Sastra memiliki pendirian bahwa tidak ada keharusan bagi seniman untuk memasuki sebuah partai, dan tidak ada larangan apabila seniman ingin memasuki sebuah partai yang sudah menjadi keyakinannya. Karena pada dasarnya seniman lahir dari masyarakat, karyanya lahir dari keadaan masyarakatyang sedangbergolak. Sehingga apabila ada seniman yang memilih untuk tidak memasuki sebuah partai, maka itu bukanlah sebuah penghalang baginya untuk menghasilkan karya yang baik. Seniman juga memiliki tugas membangun sebuah bangsa dan negara disamping tugas pemerintah, organisasiorganisasi, lembaga-lembaga, dan partaipartai. Maka melalui karyanyalah para 
seniman memberikan sumbangannya bagi pembangunan bangsa dan negara

Pandangan yang dipegang oleh Sastra dan para sastrawan yang aktif di dalamnya pada akhirnya menimbulkan reaksi terutama dari seniman Lekra karena dianggap tidak mengikuti jalannya revolusi yang belum selesai. Pramoedya Ananta Toer dalam tulisannya yang diterbitkan Lentera menyebutkan bahwa seniman yang tidak menunjukkan pendiriannya dalam berpolitik adalah seniman gelandangan, lebih lanjut Toer (dalam Mohamad, 1993, hlm. 21) menyebutkan bahwa "ketidaktegasan politik, yang menyebabkan timbulnya seni dan pemikiran gelandangan, harus disapu, harus dibabat, tidak perlu diberikan luang sekecil-kecilnya pun. Sedikit pun tak boleh dibiarkan berkembang dan berlarut unsurunsur penyakit ini, yang ternyata masih dapat mengembangkan sayapnya sampai dewasa ini."

Berbagai serangan dilakukan kepada Sastra, dimulai dari tudingan yang mengatakan bahwa Sastra adalah majalah reaksioner karena memuat dua cerita pendek karangan Bambang Sularto pada tahun 1961. Yang pertama adalah cerpen yang berjudul "Tanah" (Sularto, 1961, September), kurang lebih isi dari cerpen tersebut adalah sebagai berikut:

"mengisahkan tentang sejumlah gelandangan yang diringkus polisi karena menempati lahan luas yang di atasnya hanya terdapat lima makam Cina yang dikeramatkan. Gelandangan ini meminta kepada lurah untuk mengesahkan secara resmi pendirian kampung di tanah itu. Namun lurah tidak mengindahkan permintaan mereka sehingga menimbulkan kemarahan, mereka mengutuk lurah itu sebagai lurah peodal, begundal, komprador imperialis yang tidak pro-rakyat. Akhirnya salah seorang pemimpin dari gelandangan itu yang nampaknya sering mengikuti kajian dengan salah satu organisasi meminta bantuan kepada "kumité" untuk mendukung keinginan mereka, dan perwakilan dari "kumité" itu akhirnya datang dan menyatakan akan mendukung apa yang diinginkan oleh kumpulan gelandangan itu dengan syarat bahwa mereka (para gelandangan itu) dicatat sebagai anggota dari "kumité" tersebut dan mereka dimintai uang secara sukarela sebanyak enam rupiah setengah tiap orang dewasa. Setelah itu tenyata perkampungan yang dididirikan tanpa ijin tersebut tetap digusur oleh pemerintah setempat, dari sana pimpinan dari gelandangan itu diringkus oleh polisi untuk ditanyai dan pada akhirnya mereka mengakui kesalahan mereka dan selanjutnya perkumpulan gelandangan itu dipindahkan ke tempat penampungan yang sudah disediakan oleh negara. (hlm. 24-26).

Cerita pendek di atas dianggap tidak pro-rakyat karena menggambarkan sikap yang tidak mendukung kebutuhan rakyat akan tempat tinggalnya. Selain itu, di dalam cerita pendek itu dianggap memiliki unsur politik dengan menggambarkan adanya dukungan dari salah satu organisasi rakyat dalam mengupayakan diresmikannya tanah itu menjadi sebuah desa oleh pemerintah setempat. Hal tersebut dianggap tidak sesuai dengan 
apa yang menjadi prinsip Sastra dalam memandang hubungan antara politik dan kesenian. Pihak-pihak yang menyerang Sastra ini menganggap bahwa Sastra adalah majalah yang anti politik, sehingga cerita pendek karangan B. Sularto di atas seharusnya tidak dimuat oleh Sastra.

Selain cerpen "Tanah", karangan Bambang Sularto lainnya yang dimuat dalam Sastra juga mendapatkan tudingan yang sama, yaitu cerpen "Rapat Perdamaian” (Sularto, 1961, Oktober) isinya kurang lebih sebagai berikut:

"Mengisahkan tentang rapat disebuah kampung yang membicarakan ide perdamaian dunia. Dalam cerpen tersebut terdapat empat tokoh utama yaitu lurah sebagai pemimpin rapat, ketua RK I sebagai pemrasaran, dan ketua RK II dan RK III sebagai pihak yang menanggapi prasaran dari ketua RK I. Ketua RK I menyampaikan keadaan dunia yang sedang mengkhawatirkan timbulnya PD III, yaitu perang nuklir yang akan melikwidir seluruh umat manusia dari atas bumi yang akan pecah akibat propokasi dan napsu-angkara kaum imperialis dan kolonialis. Nampaknya pemrasaran memang pro-komunis sehingga ia menyatakan bahwa komunis tidak seharusnya kita musuhi karena komunis anti-imperialis, antikapitalis, dan anti-kolonialis. Lalu pemrasaran menyebutkan bahwa kita sebagai warga dunia harus mengadakan gerakan perdamaian, ia mengusulkan, melakukan pengumpulan tandatangan dan cap jempol yang akan diserahkan pada Panitia Gerakan Bulan Perdamaian di pusat, dan melakukan pengumpulan uang untuk membangun tugu perdamaian di kampung itu. Selanjutnya ketua RK II menyatakan setuju dengan ide perdamaian terlepas itu yang diusahakan oleh golongan manapun karena perdamaian bukanlah monopoli sesuatu golongan, tapi ia tidak setuju dengan pengumpulan uang rakyat untuk membangun tugu karena menurutnya rakyat sudah terbebani dengan iuran lainnya. Ketua RK III juga kurang setuju apabila akan dibuat tugu perdamaian dari hasil iuran rakyat, menurutnya perdamain dunia tercipta dari perdamaian dalam lingkungan yang paling kecil dan sumber dari segala perdamaian adalah perdamaian rumah tangga”. (hlm. 2324)

Cerita pendek B. Sularto yang kedua ini dianggap anti-perdamaian dunia dan antipartai. Selain itu, dalam cerita pendek ini sedikit menyinggung golongan komunis yang digambarkan melalui tokoh ketua RK I, yang mana digambarkan bahwa tokoh tersebut memiliki simpati atau perhatian lebih dengan golongan komunis. Tokoh tersebut mengusulkan agar dilakukan pemungutan iuran kepada warga untuk membangun tugu perdamaian di kampung tersebut, yang mana usulannya itu mendapatkan penolakan dari ketua RK II dan ketua RK III karena memberatkan warga. Sama seperti cerita pendek sebelumnya yaitu “Tanah”, cerita pendek "Rapat Perdamaian" juga dinyatakan mengandung unsur politik yang dianggap tidak sesuai dengan prinsip Sastra yang anti-politik. Sehingga muncullah berbagai tuduhan bahwa Sastra tidak jelas arahnya. Jika memang benar Sastra anti-politik, seharusnya Sastra tidak memuat kedua 
cerita pendek tersebut. Dan kalaupun Sastra itu berpolitik, maka politik mana yang Sastra anut.

Selain tudingan di atas, Sastra juga mendapat serangan lain yaitu berupa penolakan hadiah Sastra 1962 oleh empat pengarang, lebih lanjut Junaedhie (1995, hlm. 10) menjelaskan bahwa "tradisi Sastra sebagaimana halnya Kisah, yang memberi hadiah sastra tahunan tak urung juga diboikot. Pada tahun 1963, sejumlah pengarang yang seharusnya berhak menerima hadiah menyatakan menolak hadiah tersebut dengan alasan-alasan politik.” Empat orang pengarang yang menolak hadiah Sastra itu diantaranya Motinggo Boesje (pemenang ke-2 untuk cerpen), Virga Belan (pemenang ke-3 untuk cerpen), M. Poppy Hutagalung (pemenang ke-3 untuk puisi), dan Usamah (pemenang ke-3 untuk drama dan kisah bersambung). Alasan penolakan mereka bervariasi, namun alasan-alasan tersebut cenderung menyerang $H$. B. Jassin secara pribadi sebagai kepala redaktur majalah Sastra karena posisi Jassin sebagai kritikus sastra yang paling didengar pada saat itu. Hal tersebut tidak lain karena pendirian Jassin dan Sastra yang tidak ingin memperlihatkan haluan politiknya dan menolak apabila sastra hanya dijadikan sebagai alat propaganda bagi kepentingan pihak-pihak tertentu. Sehingga selain Sastra yang diserang, Jassinpun mendapatkan serangan terhadap kualitasnya sebagai kritikus sastra.

Dalam upaya mendapatkan kebebasan berkarya bagi para seniman yang saat itu merasa terpojok, yakni seniman yang mayoritas sering berkumpul di lingkungan Sastra maka terciptalah naskah Manifes
Kebudayaan, yaitu sebuah pernyataan pendirian dan cita-cita mengenai kebudayaan nasional Indonesia. Naskah tersebut dimuat oleh Sastra No. 9/10 1963. Naskah Manifes Kebudayaan ini terdiri dari dua bagian, bagian pertama berisi tentang naskah Manifes Kebudayaan dan bagian kedua berisi tentang Penjelasan Manifes Kebudayan. Adapun naskah Manifes Kebudayaan (Jassin, dkk, 1963a, hlm. 27) sebagai berikut:

\section{MANIFES KEBUDAJAAN}

- Kami para seniman dan tjendekiawan Indonesia dengan ini mengumumkan sebuah Manifes Kebudajaan, jang menjatakan pendirian, tjita-tjita, dan politik Kebudajaan Nasional kami.

- Bagi kami kebudajaan adalah perdjoangan untuk menjempurnakan kondisi hidup manusia. Kami tidak mengutamakan salah satu sektor kebudajaan di atas sektor kebudajaan jang lain. Setiap sektor berdjoang bersama-sama untuk kebudajaan itu sesuai dengan kodratnja.

- Dalam melasanakan kebudajaan Nasional kami berusaha mentjipta dengan kesungguhan jang sedjudjurdjudjurnya sebagai perdjoangan untuk mempertahankan dan mengembangkan martabat diri kami sebagai bangsa Indonesia di tengahtengah masjarakat bangsa-bangsa.

- PANTJASILA adalah falsafah kebudajaan kami.

$$
\text { Djakarta, } 17 \text { Agustus } 1963
$$

Dikatakan bahwa kebudayaan merupakan sebuah perjuangan untuk mengubah kondisi kehidupan manusia 
menuju kondisi yang lebih baik. Dalam perjuangan mewujudkan hal itu, semua aspek kehidupan harus berkontribusi secara seimbang. Artinya, tidak ada satu aspek kehidupan yang diutamakan dari aspek yang lain karena semua aspek adalah penting. Selanjutnya, dalam menjalankan kebudayaan nasional itu harus didasarkan pada kejujuran yang terpancar dari hati nurani, maka dari itu humanisme atau kemanusiaan itu sangatlah penting.

Menyangkut humanisme itu sendiri, dalam suasana demokrasi terpimpin ternyata menimbulkan polemik pula. Dikatakan bahwa humanisme yang dianut oleh Sastra dan Manifes Kebudayaan adalah Humanisme Universal yang dianggap tidak mengikuti jalannya revolusi yang belum selesai. Karena dalam humanisme universal itu dianggap mengaburkan kawan dan lawan. Namun dalam teks "Pendjelasan Manifes Kebudajaan" (Jassin, dkk, 1963), dijelaskan bagaimana posisi Manifes Kebudayaan terhadap humanisme universal, yaitu bahwa:

"Dalam dunia kesenian Indonesia dikenal istilah "humanisme universil". Tafsiran kami mengenai istilah itu adalah sebagai berikut: Apabila dengan "humanisme universil" dimaksudkan pengaburan kontradiksi antagonis, antara kawan dengan lawan, maka kami akan menolak "humanisme universil” itu. Sebaliknja kami menerima "humanisme universil" apabila dimaksudkan bahwa kebudajaan dan kesenian itu bukanlah semata-mata nasional, tetapi djuga menghajati nilai-nilai universil, bukan semata-mata temporal, tetapi djuga menghajati nilai-nilai eternal”. (hlm. 28)
Berdasarkan teks tersebut, terlihat bahwa sebenarnya Manifes Kebudayaan pun mempertimbangkan baik-buruknya humanisme universal bagi perjuangan memajukan kehidupan manusia Indonesia dalam lingkungan kebudayaan. Dikatakan bahwa Manifes Kebudayaan akan menolak humanisme universal apabila mengaburkan kawan dan lawan, namun Manifes Kebudayaan akan menerima humanisme universal apabila yang dimaksud didalamnya adalah kebudayaan atas dasar kemanusiaan yang tidak terikat oleh wilayah. Artinya, perjuangan dalam memajukan kehidupan manusia dari segala penindasan yang berlaku di seluruh dunia, hal tersebut di dasari karena semua manusia dimanapun ia berada pasti memperjuangkan haknya dari penindasan baik yang dilakukan oleh bangsanya sendiri ataupun oleh bangsa lain. Meskipun humanisme universal itu memiliki toleransi terhadap bangsabangsa lain, namun jangan diartikan bahwa humanisme mengaburkan mana lawan dan mana kawan, Manifes Kebudayaan tetap menarik garis pemisah antara kawan dan lawan, tetapi hal tersebut tidak pula menimbulkan sifat chauvinis.

Selanjutnya para penandatangan Manifes Kebudayaan itu merasa perlu untuk mengambil langkah yang lebih kongkrit dalam mengimplementasikan naskah Manifes Kebudayaan, maka dipersiapkanlah pelaksanaan Konferensi Karyawan Pengarang se-Indonesia. Teeuw (1989) menjelaskan bahwa seharusnya Sastra-lah yang mensponsori konferensi tersebut karena majalah ini satu-satunya majalah yang mendukung Manifes Kebudayaan sejak awal, namun keterbatasan keadaan keuangan tidak 
memungkinkan hal tersebut, lebih jelas Teeuw menjelaskan bahwa:

"Para penandatangan Manikebu menyadari bahwa manifesto itu perlu diikuti dengan langkah-langkah lain sebagai tindak lanjut, dan bahwa dunia kebudayaan di Indonesia sedang menunggu-nunggu prakarsa baru dari mereka. Maka, dipustuskanlah untuk menyelenggarakan konperensi kebudayaan seluruh Indonesia di Jakarta, di bawah nama Konperensi Karyawan Pengarang se-Indonesia (KKPI) selama seminggu pada 1-7 Maret 1964. Konperensi ini semestinya disponsori oleh majalah Sastra, satusatunya juru bicara gagasan sastra nonkiri yang masih ada. Tetapi jelas bahwa baik Sastra maupun organisasi kebudayaan lain tidak akan mempunyai dana untuk menyelenggarakan kegiatan yang besar-besaran seperti itu. Sementara itu, masalah keuangan, khususnya biaya perjalanan bagi para peserta dari seluruh Indonesia, pun tak akan mungkin teratasi tanpa adanya dukungan dari luar". (hlm. 40)

Ketika KKPI membutuhkan sponsor dalam mendukung acara besar itu, maka muncullah dukungan dari Angkatan Bersenjata dengan maksud untuk menggalang kekuatan di bidang kebudayaan dalam mengimbangi dominasi PKI di Indonesia. Nampaknya mulai ada keresahan dalam angkatan bersenjata Indonesia melihat pengaruh komunis yang mulai melebarkan sayapnya di Indonesia, sehingga angkatan bersenjata-pun datang untuk mesponsori KKPI ini, lebih lanjut Teeuw (1989) menjelaskan bahwa:

Maka, tampillah Angkatan Darat sebagai penyelamat penyelenggara.
Angkatan Darat dan Panglima Besarnya, $\mathrm{AH}$ Nasution khususnya, sangat menyadari arti penting peristiwa ini sebagai jalan untuk menggalang kekuatankekuatan anti PKI di bidang kebudayaan, dan oleh karena itulah ia menyediakan dana dan kemudahan lain-lain untuk memungkinkan terselenggaranya konperensi itu. Jumlah tepatnya peserta konperensi tidak diketahui, tetapi sudah pasti antara 1.500 dan 2.000 orang. Dan banyak organisasi yang terwakili pula (hlm. 40).

Setelahmenjalankankonferensidengan baik, akhirnya KKPI ini menghasilkan Persatuan Karyawan Pengarang Indonesia dan beberapa buah dokumen yang dimuat pula dalam Sastra, seperti Mukadimah Konperensi Karyawan Pengarang seIndonesia (Sastra, 1964, No. 1, hlm. 7), Keputusan-keputusan Sidang Paripurna Konperensi Karyawan Pengarang seIndonesia (Sastra, 1964, No. 2, hlm. 32-33) dan Ikrar Pengarang Indonesia (Sastra, 1964, No. 2, hlm. 33). Namun disamping keberhasilan penyelenggaraan KKPI ini, ada sebuah penjelasan yang disampaikan Goenawan Mohamad yang merasa konferensi tersebut sebenarnya mengalami kegagalan, karena menurutnya apa yang dibahas dalam konferensi itu tidak sesuai dengan niat awal yaitu untuk membahas Manifes Kebudayaan. Hal tersebut terjadi karena sejak awal pembukaan acara tersebut yang dibuka oleh pidato Menteri Pendidikan dan Kebudayaan Prijono serta Jenderal Nasution selaku Kepala Staf Angkatan Bersenjata, yang mana keduanya tidak menyetujui Manifes Kebudayaan. Sehingga pada akhirnya kalangan Manifes Kebudayaan harus mengalah untuk tidak membicarakan hal tersebut demi kelancaran pelaksanaan konferensi. 
Baik Manifes Kebudayaan maupun KKPI, keduanya mendapatkan serangan dari seniman yang sejak awal telah memiliki pandangan negatif terhadap $\neg$ Sastra maupun Manifes Kebudayaan. Serangan tersebut mayoritas berupa tulisan ataupun karikatur yang sebagian besar dimuat dalam Bintang Timur yaitu surat kabar yang dimiliki PKI. Hingga akhirnya Manifes Kebudayaan secara resmi dinyatakan terlarang oleh Presiden Sukarno pada tanggal 8 Mei 1964 karena dianggap menyaingi Manifesto Politik Indonesia.

Pelarangan ini menjadi pemicu berhentinya Sastra dalam peredaran, meskipun tidak secara resmi pemerintah mencabut izin terbit Sastra. Tapi karena sudah mendapatkan cap sebagai majalah reaksioner yang menentang pemerintah, maka Sastra-pun tidak laku dipasaran. Seperti yang terjadi di Solo (Moeljanto \& Ismail, 1995, hlm. 382-383), bahwa "toko buku agen tunggal majalah Sastra di Solo menerangkan bahwa kiriman majalah Sastra nomor terbaru telah diretur kembali dari Solo, karena Wong Solo emoh Sastra." Selain itu, tim redaksi Sastra dan para pendukung Manifes Kebudayaan terus terpojok. Banyak pihak yang menuntut agar semua pendukung Manifes Kebudayaan segera diberhentikan dari pekerjaannya karena dikhawatirkan menyebarkan ide-ide Manifes Kebudayaan yang sudah dilarang.

\section{SIMPULAN}

Majalah Sastra adalah majalah kebudayaan yang diterbitkan pada tahun 1961 atas prakarsa H. B. Jassin. Latar belakang terbitnya majalah ini karena Jassin merasa dibutuhkan suatu wadah pada masa itu yang menyediakan bacaan yang baik bagi masyarakat. Disamping itu, majalah ini juga berusaha untuk memperluas peminat sastra di Indonesia dengan menyediakan lahan bagi para pengarang baik yang sudah memiliki nama ataupun masih pemula untuk mempublikasikan karyanya.

Berbeda dengan media massa lainnya baik dalam bentuk majalah maupun surat kabar masa Demokrasi Terpimpin, Sastra cenderung tidak memperlihatkan warna politiknya. Padahal dalam masa itu, media massa umumnya memperlihatkan corak politiknya untuk mendukung jalannya revolusi yang belum selesai. Sastra berpendapat bahwa untuk mendukung jalannya revolusi yang belum selesai, sebuah media massa tidak harus memperlihatkan keberpihakan politiknya. Hal tersebut juga berlaku dalam pandangan Sastra terhadap kebudayaan, yaitu bahwa kebudayaan Indonesia adalah kebudayaan yang tidak berpihak, kebudayaan yang jujur yang lahir dari kondisi masyarakat yang sedang bergejolak. Kebudayaan dalam pandangan Sastra adalah kebudayaan yang mengutamakan kemanusiaan. Dalam melihat posisi kebudayaan dan politik yang saat itu menjadi persoalan, Sastra memandang bahwa baik kebudayaan maupun politik, keduanya adalah unsur yang penting bagi Indonesia, keduanya seimbang, sehingga tidak ada yang lebih unggul dari yang lainnya. Apa yang menjadi pendangannya mengenai kebudayaan itu juga berpengaruh kepada pandangan Sastra dalam melihat posisi seorang seniman, bahwa untuk menghasilkan karya yang baik yang mendukung jalannya revolusi yang belum selesai seorang seniman tidak harus menyatakan pendirian politiknya dengan memasuki 
sebuah organisasi atau partai politik, karena seniman adalah hati nuraninya masyarakat maka dengan sendirinya ia akan mengabdi kepada kepentingan rakyat meskipun tidak berpatok pada sloganslogan partai. Apabila seniman terlalu mengacu pada slogan-slogan kepentingan partai dikhawatirkan akan terjadinya penyempitan pengalaman seorang seniman sehingga seniman tersebut tidak berkembang.

Dengan pandangan Sastra yang tidak sama dengan pandangan pada umumnya, otomatis Sastra mendapatkan perlawanan. Mulai dari adanya tudingan bahwa Sastra adalah majalah reaksioner hingga adanya penolakan terhadap hadiah Sastra 1962, dan akhirnya banyak yang menuntut agar Sastra dicabut izin terbitnya. Untuk memperjuangkan pendiriannya itu, Sastra dan para pendukungnya melakukan berbagai upaya, diantaranya adalah dengan melahirkan Manifes Kebudayaan yaitu suatu pernyataan pendirian sekelompok seniman mengenai kebudayaan nasional Indonesia dan juga sebuah upaya agar seniman bisa mendapatkan kebebasan berkarya tanpa ada paksaan maupun tekanan dari pihak lain. Dan untuk merealisasikan apa yang tertuang dalam naskah Manifes Kebudayaan itu maka dilaksanakanlah Konferensi Karyawan Pengarang se-Indonesia (KKPI). Konferensi itu berjalan dengan baik dan mengasilkan pembentukan Persatuan Karyawan Pengarang Indonesia (PKPI), namun inti pembicaraan yang direncanakan yaitu mengenai Manifes Kebudayaan tidak disinggung sama sekali. Karena para petinggi yang datang nyatanya juga tidak mendukung Manifes Kebudayaan.
Baik Manifes Kebudayaan maupun KKPI, keduanya mendapatkan perlawanan daripihakyangtidaksetuju denganapayang menjadi pendirian Manifes Kebudayaan. Berbagai artikel dan karikatur yang isinya menyudutkan Manifes Kebudayaan dan KKPI dimuat dalam berbagai surat kabar terutama dilakukan oleh Bintang Timur sebagai surat kabar milik PKI. Hingga akhirnya Manifes Kebudayaan dinyatakan terlarang oleh Presiden Sukarno karena dianggap menyaingi Manifesto Politik Indonesia yang dijadikan Garis Besar Haluan Negara.

Dampak yang diterima Sastra akibat mempertahankan pendiriannya itu sebenarnya telah dirasakan semenjak tahun pertama penerbitannya dengan adanya tudingan-tudingan yang datang hingga pemboikotan hadiah Sastra 1962. Namun dampak yang paling dirasakan adalah semenjak Manifes Kbeudayaan dinyatakan terlarang. Sastra yang merupakan wadah berkumpulnya para pendukung Manifes Kebudayaan dengan otomatis mendapatkan imbasnya. Memang pemerintah tidak mencabut izin terbit majalah Sastra, tapi dengan tekanan terhadap Manifes Kebudayaan dan para pendukungnya, Sastra menjadi kehilangan sumber pemasukan. Hal tersebut terjadi karena ada penolakan terhadap majalah ini seperti yang terjadi di Solo yang mana Sastra tidak laku di pasaran dan juga karena tim redaksi Sastra terus diserang sehingga menjadi terpojok. Hingga akhirnya para pendukung Manifes Kebudayaan dan tim redaksi Sastra termasuk di dalamnya memutuskan untuk menarik diri. 


\section{DAFTAR PUSTAKA}

\section{Buku}

Eneste, P. (1987). H. B. Jassin Paus Sastra Indonesia. Jakarta: Djambatan.

Gottschalk, L. (2008). Mengerti Sejarah. Jakarta: Penerbit Universitas Indonesia.

Hae, Z. (2014). Se(r)Ikat Puisi dari Tanah Air Tanpa Batas. Kalam, 26, hlm. 1-44. Ismaun. (2005). Pengantar Belajar Sejarah sebagai Ilmu dan Wahana Pendidikan. Bandung: Historia Utama Press.

Jassin, H. B., dkk. (1961a). Susunan Tim Redaksi Madjalah Sastra. Sastra, (1), hlm. 2.

Jassin, H. B., dkk. (1961b). Kisah Terbit Kembali (Sebuah Kata Kegembiraan). Sastra, (1), hlm. 3.

Jassin, H. B., dkk. (1962). Satu Tahun Sastra Pernjataan Sikap dan Pertanggungandjawab. Sastra, (1), hlm. 3-5.

Jassin, H. B., dkk. (1963a). Naskah Manifes Kebudajaan. Sastra, (9/10), hlm. 27.

Jassin, H. B., dkk. (1963b). Pendjelasan Manifes Kebudajaan. Sastra, (9/10), hlm. 28-29.

Jassin, H. B., dkk. (1964). Masuk Tahun Keempat (Tahun Konfrontasi). Sastra, (1), hlm. 4-6.

Jassin, H. B. (1984). Surat-surat 19431983. Jakarta: P.T. Gramedia.

Junaedhie, K. (1995). Rahasia Dapur Majalah di Indonesia. Jakarta: PT Gramedia Pustaka Utama.
Moeljanto, D. S. \& Ismail, T. (1995). Prahara Budaya Kilas Balik Ofensif Lekra/ dkk. Bandung: Mizan.

Mohamad, G. (1993). Kesusastraan dan Kekuasaan. Jakarta: PT Pustaka Firdaus.

Notosusanto, N. (1954). Situasi 1954 II Mythe Kelesuan. Kompas, (7), hlm. 46-50.

Rosidi, A. (1968). Ikhtisar Sejarah Sastra Indonesia. Bandung: Binacipta.

Soedjatmoko. (1954, No. 1). Mengapa Konfrontasi?. Konfrontasi, (1), hlm. 3-12.

Sularto, B. (1961, September). Tanah. Sastra, (5), hlm. 24-26.

Sularto, B. (1961, Oktober). Rapat perdamaian. Sastra, (6), hlm. 23-24.

Supriatna, N. (2018). Prosa dari Praha. Bandung: PT. Remaja Rosdakarya.

Teeuw, A. (1989). Sastra Indonesia Modern Jilid II. Jakarta: P.T. Dunia Pustaka Jaya.

\section{Jurnal}

Foulcher, K. (1969). A Survey of Events Surrounding Manikebu. The Struggle for Cultural and Intellectual Freedom in Indonesian Literature. Bijdragen tot de Taal-, Land- en Volkenkunde, 125 (4), hlm. 429-465.

Suwirta, A. (2008). Dinamika Kehidupan Pers di Indonesia pada Tahun 19501965: Antara Kebebasan dan Tanggung Jawab Nasional. Sosiohumanika, 1 (2), 47-85. 